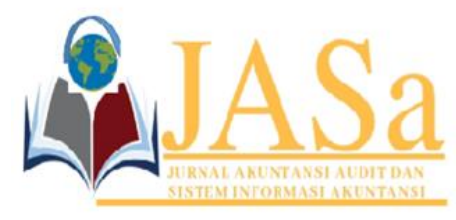

JASa (Jurnal Akuntansi, Audit dan Sistem Informasi Akuntansi)

Vol. 5 No.1/ April 2021

ISSN 2550-0732 print / ISSN 2655-8319 online

DOI; $10.36555 /$ jasa.v5i1.1598

\title{
THE INFLUENCE OF ORGANIZATIONAL CULTURE ON THE QUALITY OF MANAGEMENT ACCOUNTING INFORMATION SYSTEMS AND ITS IMPACT ON MANAGERIAL PERFORMANCE
}

\author{
Uswatun Hasanah ${ }^{*}$, Dwioctavia Ningrum ${ }^{2}$, Indri Alya Rahayu ${ }^{3}$ \\ Universitas Langlangbuana, Indonesia *1 23 \\ uswatun.hasanah489@gmail.com*1 \\ octavianingrum dwi@yahoo.com² indrialya16@gmail.com³
}

\begin{abstract}
Organizational culture is an important environmental problem for an organization. Managers must understand that culture is an important determinant that affects how well the organization will perform, then. Information systems must be managed based on appropriate methods and methods to strengthen the assumption that the accounting information system implemented by management will affect company performance and that management accounting information systems are not bound by formal criteria that can explain the nature of the input, process, and output. This study aims to determine the effect of organizational culture on the quality of management accounting information systems and its impact on managerial performance. This study uses a causal relationship (cause and effect). The data were collected using a survey method by distributing questionnaires directly to the Bhayangkara Tk Hospital. II Sartika Asih Bandung. The sampling technique was processed using cluster random sampling, amounting to 90 respondents, the data analysis was processed using SEM-PLS using explanatory research. The results obtained indicate that organizational culture has an effect on the quality of the management accounting information system and the quality of the management accounting information system has an effect on managerial performance.
\end{abstract}

Keywords: Organizational Culture, Quality of Management Accounting Information Systems, Managerial Performance.

\section{INTRODUCTION}

Organizational culture is an important environmental problem for an organization. Managers must understand that culture is an important determinant that affects how well an organization will perform, therefore culture can be determined and managed in several different ways (Tobari, 2014: 183). Information systems must be managed based on appropriate methods and methods to reinforce the notion that the accounting information system run by management will affect company performance. According to Salman and Farid (2016: 3), management accounting information systems are not bound by formal criteria which can explain the nature of the input, process, and output. These criteria are flexible in terms of the goals to be achieved by management. In facing challenges in the increasingly complex business world, organizations should have the ability to manage their organizations very well. According to Noermijati (2013: 41) says that managerial performance is a combination that comes from knowledge (knowledge) 


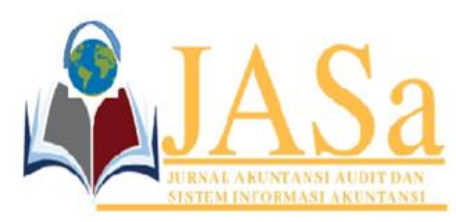

JASa (Jurnal Akuntansi, Audit dan Sistem Informasi Akuntansi)

Vol. 5 No.1/ April 2021

ISSN 2550-0732 print / ISSN 2655-8319 online

DOI;10.36555/jasa.v5i1.1598

with the ability to apply skills into practice. The purpose of conducting this research is to find out the truth, as stated by Kadri (2018: 57) says that the research objective is a series of statements about what is desired and achieved for activities carried out consistently that focus on solving problems that have been formulated. According to Kreitner and Kinichi (2014: 62) say that organizational culture is a set of assumptions that are shared and accepted implicitly and held by a group that will determine how it is felt, thought about, and reacts to the various environments in each. action is taken.

according to Ingga (2017: 5) says that management accounting information is a system for preparing financial information whose output will be conveyed to internal parties or management as information for decision making, planning, and control.

Then according to Romney and Steinbart (2016: 2) say that a series of managerial accounting activities are related to providing information to managers used in an organization.

The influence of organizational culture $(X)$ on the quality of the management accounting information system $(Y)$ and its impact on managerial performance $(Z)$.

Research Hypothesis

$\mathrm{H} 1$ : The influence of Organizational Culture on the Quality of Management Accounting Information Systems at Bhayangkara Hospital, Tk. II Sartika Asih Bandung.

H2: The influence of the Quality of Management Accounting Information Systems on Managerial Performance at Bhayangkara Hospital, Tk. II Sartika Asih Bandung.

\section{METHODS}

According to Siregar (2016: 110), the dependent variable is a variable that is influenced or becomes the result of other variables (independent variables). This variable is also often called the dependent variable, response variable or endogenous. In this study, all variables used an ordinal scale. Sources of data used in this study are primary data and secondary data. The method of data collection is by distributing 90 questionnaires to the employees of the Bhayangkara Tk Hospital. II Sartika Asih Bandung. The sampling technique in this study is to use cluster random sampling to the employees of the Bhayangkara Tk Hospital. II Sartika Asih Bandung by profession. This study uses validity and reliability tests to measure the validity and reliability of data. This study used a descriptive method with data analysis techniques using SEM-PLS.

\section{Organizational Culture Measurement Model}

\section{RESULTS AND DISCUSSION}

In this study, organizational culture variables were measured using seven dimensions, namely innovation and risk-taking, attention to detail, results from orientation, people orientation, team orientation, aggressiveness, and stability. The results of the estimates obtained from the measurement model parameters on the organizational culture variables can be explained as follows. 


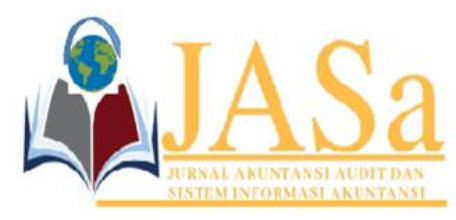

JASa (Jurnal Akuntansi, Audit dan Sistem Informasi Akuntansi)

Vol. 5 No.1/ April 2021

ISSN 2550-0732 print / ISSN 2655-8319 online

DOI;10.36555/jasa.v5i1.1598

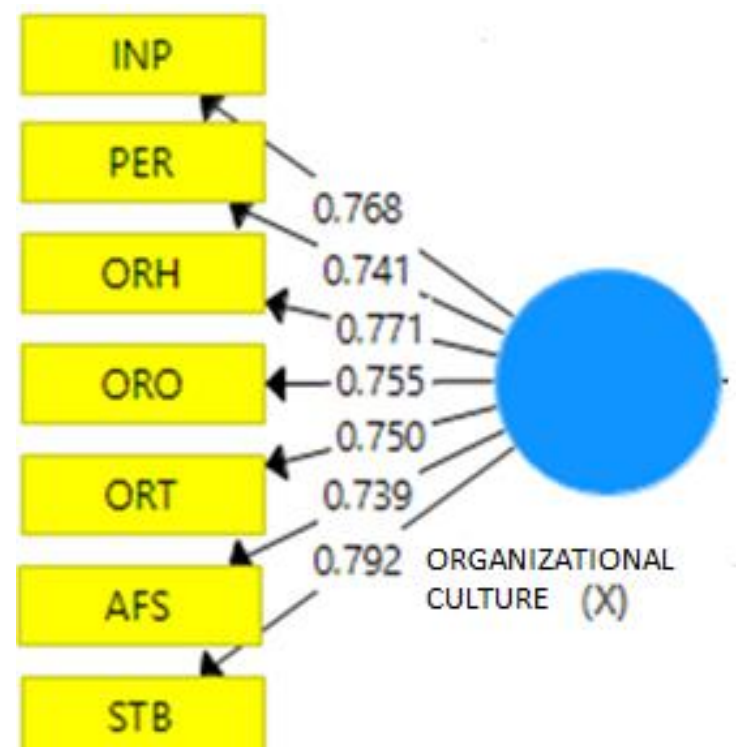

Figure 1. Organizational Culture Path Diagram

Source: data processed by SEM-PLS

From the organizational culture cycle diagram above, it can be seen that the value contained in each indicator is generated through dimensions derived from reflective organizational culture variables. The results of the calculation of the organizational culture measurement model are as follows:

Table 1. Results of the Calculation of the Organizational Culture Measurement Model

\begin{tabular}{lcccc}
\hline \multicolumn{1}{c}{ Item } & $\begin{array}{c}\text { Loading } \\
\text { Factor }\end{array}$ & $\begin{array}{c}\text { Indicator } \\
\text { Reliability }\end{array}$ & t-count & p-value \\
\hline Innovation and taking risks & 0,768 & 0,771 & 16,763 & 0,000 \\
Attention to detail & 0,741 & 0,742 & 10,035 & 0,000 \\
Result orientation & 0,771 & 0,775 & 11,198 & 0,000 \\
Orientation to people & 0,755 & 0,751 & 12,488 & 0,000 \\
Team orientation & 0,750 & 0,743 & 10,406 & 0,000 \\
Aggressiveness & 0,739 & 0,732 & 10,779 & 0,000 \\
Stability & 0,792 & 0,793 & 9,670 & 0,000 \\
Average Variance Extracted & \multicolumn{5}{c}{0,580} \\
(AVE) & \multicolumn{3}{c}{0,904} \\
Construct Reliability & \multicolumn{5}{c}{} \\
\hline
\end{tabular}

Source: data processed by SEM-PLS 


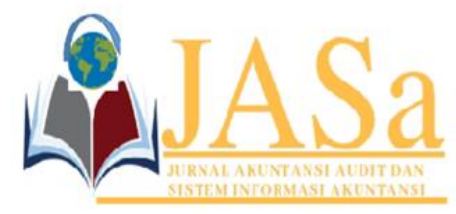

JASa (Jurnal Akuntansi, Audit dan Sistem Informasi Akuntansi)

Vol. 5 No.1/ April 2021

ISSN 2550-0732 print / ISSN 2655-8319 online

DOI;10.36555/jasa.v5i1.1598

On the outer loading and reflective constructs of measuring organizational culture, each dimension has a value above 0.50. In this study, the dimensions of innovation and attention to detail show the value of a loading factor of 0.768 , this explains that the value displayed is above 0.50 and is significant $(p=0.000)$ with a real level of $5 \%$ and has a reliability indicator of 0.771 . Furthermore, the dimension of attention to detail shows the loading factor value of 0.741 , this explains that the value displayed is above 0.50 and is significant $(p=0.000)$ with a real level of $5 \%$ and has a reliability indicator of 0.742 . Then the orientation dimension of the results shows the loading factor value of 0.771 , this explains that the value displayed is above 0.50 and is significant $(p$ $=0.000$ ) with a real level of $5 \%$ and has a reliability indicator of 0.775 . Furthermore, the dimension of orientation in people shows a loading factor value of 0.755 , this explains that the value displayed is above 0.50 and is significant $(p=0.000)$ with a real level of $5 \%$ and has an indicator of the reliability of 0.751 . Then the orientation dimension on the team shows the loading factor value of 0.750 , this explains that the value displayed is above 0.50 and is significant $(p=0.000)$ with a real level of $5 \%$ and has a reliability indicator of 0.743 . Furthermore, the aggressiveness dimension shows the loading factor value of 0.735 , this explains that the displayed value is above 0.50 and is significant $(p$ $=0.000$ ) with a significant level of $5 \%$ and has a reliability indicator of 0.732 . Furthermore, the stability dimension shows the loading factor value of 0.792 , this explains that the value displayed is above 0.50 and is significant $(p=0.000)$ with a significant level of $5 \%$ and has a reliability indicator of 0.793 . The composite reliability value is 0.904 which is at an interval of 0.8 so that it is still acceptable to show that the reflective construct of organizational culture has a good consistency interval level with an AVE value of 0.580 which indicates that the value is above the minimum level of 0.50 . of this reflective construct has a good level of convergent reliability. In this study, discriminant validity was tested through cross-loading described in table 1 which shows that there are dimensions that have loading values for the construct, while all cross-loading with other constructs is quite low so this proves discriminant validity for the construct of organizational culture.

\section{Management Accounting Information System Quality Measurement Model}

In this study, the variable quality of management accounting information systems is measured using four dimensions, namely broad scope, aggressiveness, timeliness, and integration. The results of the estimation obtained from the measurement mode parameter on the quality variable of this management accounting information system can be explained as follows: 


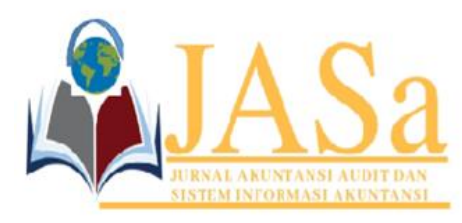

JASa (Jurnal Akuntansi, Audit dan Sistem Informasi Akuntansi)

Vol. 5 No.1/ April 2021

ISSN 2550-0732 print / ISSN 2655-8319 online

DOI;10.36555/jasa.v5i1.1598

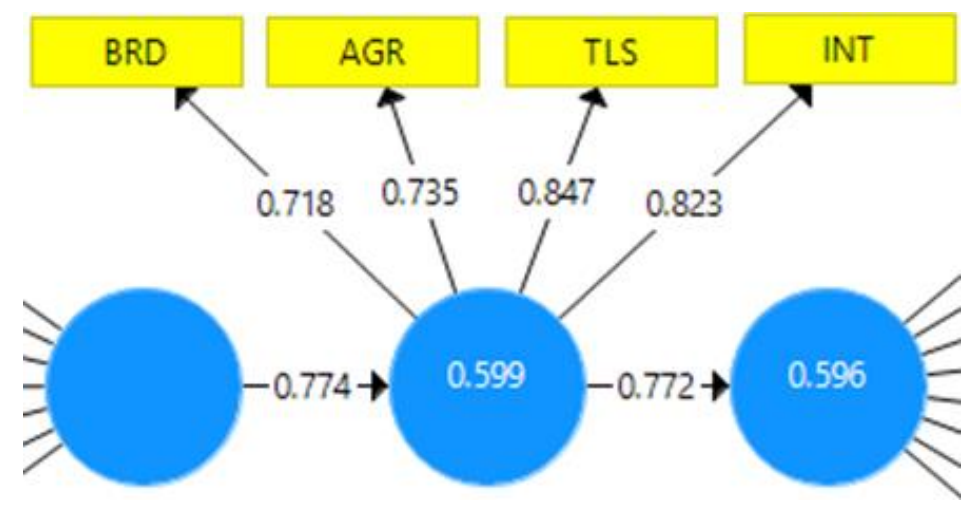

Figure 2. Path diagram of the quality of Management Accounting Information Systems Source: data processed by SEM-PLS

From the path diagram of the management accounting information system quality above, it can be seen that the value contained in each indicator is generated through the dimensions derived from the reflective management accounting information system quality variables. The results of the calculation of the management accounting information system quality measurement model are as follows:

Table 2. Results of the calculation of the measurement model for the quality of management accounting information systems

\begin{tabular}{lcccc}
\hline \multicolumn{1}{c}{ Item } & $\begin{array}{c}\text { Loading } \\
\text { Factor }\end{array}$ & $\begin{array}{c}\text { Indicator } \\
\text { Reliability }\end{array}$ & t-count & p-value \\
\hline Broadscope & 0,718 & 0,712 & 6,565 & 0,000 \\
Aggregation & 0,735 & 0,732 & 10,779 & 0,000 \\
Timeliness & 0,847 & 0,846 & 19,603 & 0,000 \\
Integration & 0,823 & 0,819 & 15,997 & 0,000 \\
Average Variance Ectracted & \multicolumn{4}{c}{0,612} \\
(AVE) & \multicolumn{4}{c}{0,860} \\
Construct Reliability & Source: data processed by SEM-PLS \\
\hline \multicolumn{4}{l}{}
\end{tabular}

On the outer loading and reflective constructs on the measurement of management accounting information systems, each dimension has a value above 0.50 . In this study, the broad scope dimension shows the loading factor value of 0.718 , this explains that the value displayed is above 0.50 and is significant $(p=0.000)$ with a significant level of $5 \%$ and has a reliability indicator of 0.712 . Furthermore, the aggregation dimension shows the loading factor value of 0.735 , this explains that the value displayed is above 0.50 and is significant $(p=0.000)$ with a real level of $5 \%$ and 


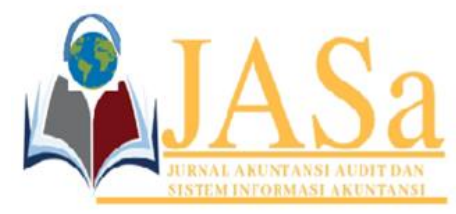

JASa (Jurnal Akuntansi, Audit dan Sistem Informasi Akuntansi)

Vol. 5 No.1/ April 2021

ISSN 2550-0732 print / ISSN 2655-8319 online

DOI;10.36555/jasa.v5i1.1598

has a reliability indicator of 0.732 . Then the timeliness dimension shows the loading factor value of 0.847 , this explains that the value displayed is above 0.50 and is significant $(p=0.000)$ with a real level of $5 \%$ and has a reliability indicator of 0.846 . Furthermore, the integration dimension shows a loading factor value of 0.823 , this explains that the value displayed is above 0.50 and is significant $(p=0.000)$ with a significant level of $5 \%$ and has a reliability indicator of 0.819 . The composite reliability value is 0.860 which is in the interval 0.8 so that it is still acceptable to show that the reflective construct of organizational culture has a good consistency interval level with an AVE value of 0.612 which indicates that the value is above the minimum level of 0.50 . of this reflective construct has a good level of convergent reliability. In this study, discriminant validity was tested through cross-loading which is described in table 2 which shows that there are dimensions that have loading values for the construct while all cross-loading with other constructs is quite low so this proves discriminant validity for the construct of quality management accounting information systems.

\section{Managerial Performance Measurement Model}

In this study, the managerial performance variables were measured using eight dimensions, namely planning, investigation, coordination, evaluation, supervision, staffing, negotiation, and representation. The results of the estimation obtained from the measurement model parameters on this managerial performance variable can be explained as follows:

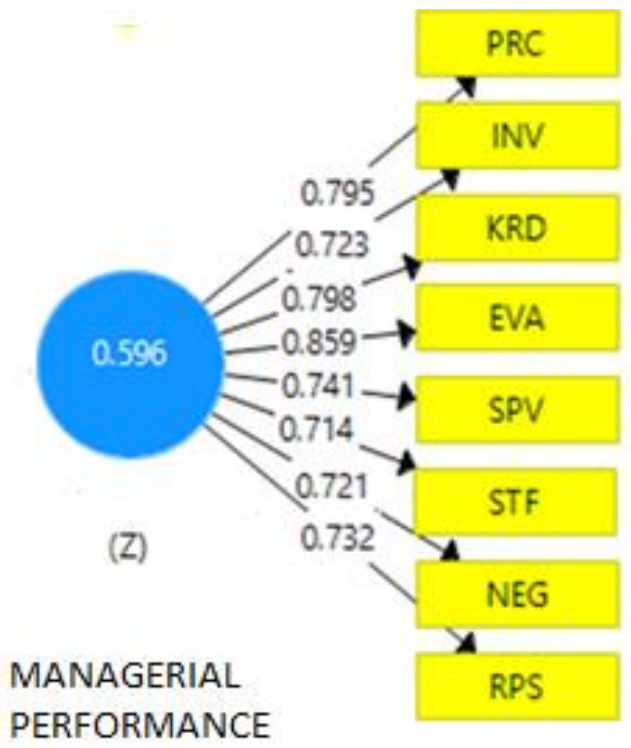

Figure 3 Managerial Performance Path Diagram Source: data processed by SEM-PLS

Submitted: March 31, 2021; Accepted: April 04, 2021; 


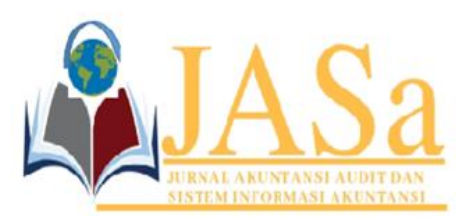

JASa (Jurnal Akuntansi, Audit dan Sistem Informasi Akuntansi)

Vol. 5 No.1/ April 2021

ISSN 2550-0732 print / ISSN 2655-8319 online

DOI;10.36555/jasa.v5i1.1598

From the managerial performance path diagram above, the values contained in each indicator can be determined through dimensions derived from reflective managerial performance variables.

The results of the calculation of the managerial performance measurement model are as follows:

Table 3. Results of the Calculation of the Managerial Performance Measurement Model

\begin{tabular}{lcccc}
\hline \multicolumn{1}{c}{ Item } & $\begin{array}{c}\text { Loading } \\
\text { Factor }\end{array}$ & $\begin{array}{c}\text { Indicator } \\
\text { Reliability }\end{array}$ & t-count & p-value \\
\hline Planning & 0,795 & 0,786 & 11,368 & 0,000 \\
Investigation & 0,723 & 0,720 & 11,128 & 0,000 \\
Coordination & 0,798 & 0,794 & 11,603 & 0,000 \\
Evaluation & 0,859 & 0,858 & 24,969 & 0,000 \\
Supervision & 0,741 & 0,728 & 9,290 & 0,000 \\
Staffing & 0,714 & 0,717 & 7,889 & 0,000 \\
Negotiation & 0,721 & 0,727 & 10,235 & 0,000 \\
Representation & 0,723 & 0,727 & 8,225 & 0,000 \\
Average Variance Ectracted & \multicolumn{5}{c}{0,581} \\
(AVE) & Source: data processed by SEM-PLS \\
Construct Reliability & \multicolumn{5}{c}{0,915} \\
\hline
\end{tabular}

On outer loading and the reflective construct on the measurement of managerial performance, each dimension has a value above 0.50. In this study, the planning dimension shows the loading factor value of 0.795 , this explains that the value displayed is above 0.50 and is significant $(p=0.000)$ with a significant level of $5 \%$ and has a reliability indicator of 0.786 . Furthermore, the investigation dimension shows the loading factor value of 0.723 , this explains that the value displayed is above 0.50 and is significant $(p=0.000)$ with a real level of $5 \%$ and has a reliability indicator of 0.720 . Then the coordination dimension shows the loading factor value of 0.798 , this explains that the value displayed is above 0.50 and is significant $(p=0.000)$ with a significant level of $5 \%$ and has an indicator of the reliability of 0.794 .

Furthermore, the evaluation dimension shows the loading factor value of 0.859 , this explains that the value displayed is above 0.50 and is significant $(p=0.000)$ with a significant level of $5 \%$ and has a reliability indicator of 0.858 . Then the supervision dimension shows the loading factor value of 0.741 , this explains that the value displayed is above 0.50 and is significant $(p=0.000)$ with a real level of $5 \%$ and has a reliability indicator of 0.728 . Furthermore, the staffing dimension shows the loading factor value of 0.714 , this explains that the value displayed is above 0.50 and is significant $(p=0.000)$ with a real level of $5 \%$ and has a reliability indicator of 0.717 . Then the negotiation dimension shows the loading factor value of 0.721 , this explains that the value displayed is above 0.50 and is significant $(p=0.000)$ with a real level of $5 \%$ and has a reliability 


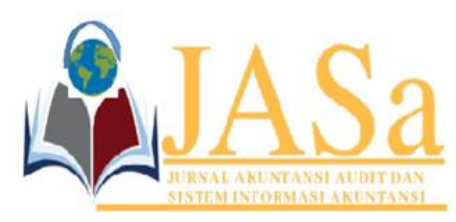

\author{
JASa (Jurnal Akuntansi, Audit dan Sistem Informasi Akuntansi) \\ Vol. 5 No.1/ April 2021 \\ ISSN 2550-0732 print / ISSN 2655-8319 online \\ DOI;10.36555/jasa.v5i1.1598
}

indicator of 0.727 . Furthermore, the representation dimension shows the loading factor value of 0.723 , this explains that the value displayed is above 0.50 and is significant ( $p$ $=0.000$ ) with a significant level of $5 \%$ and has a reliability indicator of 0.727 . The composite reliability value is 0.915 which is at an interval of 0.8 so that it is still acceptable to show that the reflective construct of managerial performance has a good consistency interval level with an AVE value of 0.581 which indicates that the value is above the minimum level of 0.50 . of this reflective construct has a good level of convergent reliability. In this study, discriminant validity was tested through cross-loading which is described in table 4.27 which shows that there are dimensions that have loading values for the construct while all cross-loading with other constructs is quite low so this proves discriminant validity for the managerial performance construct.

\title{
Collinearity Testing
}

The explanation of collinearity testing in this study is to explain the causality relationship between the variables in the study. To evaluate collinearity, it is used for variance inflation factor (VIF) in the context of PLS-SEM, a tolerance value of 0.20 or less and a VIF value of 5 or more indicates a collinearity problem (Hair et al, 2014: 186).

Table 4. Collinearity Assessment

\begin{tabular}{lc}
\hline \multicolumn{1}{c}{ Konstruk } & VIF \\
\hline Organizational culture & 1,000 \\
Quality of Management Accounting & 1,000 \\
Information Systems & \\
\hline
\end{tabular}

Source: data processed by SEM-PLS

Dari hasil perhitungan, diketahui nilai VIF dari setiap variabel budaya organisasi dan kualitas sistem informasi akuntansi manajemen dalam tabel. Nilai VIF di luar nilai toleransi untuk perbedaan problem colinearity, sehingga dapat disimpulkan bahwa tidak terdapat tingkat collinearity yang signifikan di antara kedua variabel prediktor tersebut, dengan evaluasi model struktural dapat direalisasikan dengan meliputi pengujian yang dilakukan melalui dua tahap hipotesis penelitian.

\section{Structural Model Evaluation}

From the calculation of standardized path coefficients for structural models the influence of organizational culture on the quality of management accounting information systems and its impact on managerial performance.

shown in the following image:

Submitted: March 31, 2021; Accepted: April 04, 2021;

Published: April 24, 2021; Website: http://journalfeb.unla.ac.id/index.php/jasa 


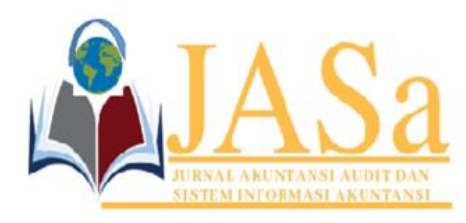

JASa (Jurnal Akuntansi, Audit dan Sistem Informasi Akuntansi)

Vol. 5 No.1/ April 2021

ISSN 2550-0732 print / ISSN 2655-8319 online

DOI;10.36555/jasa.v5i1.1598

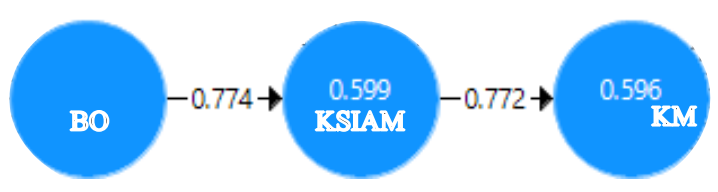

Figure 4. Standardized Structural Model Coefficients Source: data processed by SEM-PLS

Hypothesis testing

Statistical Hypothesis 1

$\mathrm{H}_{0}: \gamma_{11}=0$ : Organizational culture does not affect the quality of the management accounting information system

$\mathrm{H}_{0}: \gamma_{11} \neq 0$ : Organizational culture has a significant effect on the quality of the management accounting information system

Statistical Hypothesis 2

$\mathrm{H}_{0}: \beta_{21}=0$ : The quality of the management accounting information system does not affect managerial performance

$\mathrm{H}_{0}: \beta_{21} \neq 0$ : The quality of the management accounting information system has an effect significant managerial performance

In testing the hypothesis in this study, t-student was used as described in the previous chapter. The test criterion is that $\mathrm{HO}$ is rejected if the $\mathrm{p}$-value is smaller than $\alpha$, with $\alpha=$ 0.05 , the test results are summarized in the following table:

Table 5. Hypothesis Testing Results

\begin{tabular}{ccccc}
\hline $\begin{array}{c}\text { Statistical } \\
\text { Hypothesis }\end{array}$ & $\begin{array}{c}\text { Path } \\
\text { Coefficient }\end{array}$ & t-count & p-value & Information \\
\hline $\mathrm{H}_{0}: \mathrm{Y}_{11}=0$ & 0,774 & 18,144 & 0,000 & $\mathrm{H}_{0}$ rejected \\
$\mathrm{H}_{0}: \mathrm{Y}_{11} \neq 0$ & & & & \\
$\mathrm{H}_{0}: \beta_{21}=0$ & 0,772 & 20,839 & 0,000 & $\mathrm{H}_{0}$ rejected \\
$\mathrm{H}_{0}: \beta_{21} \neq 0$ & & & & \\
\hline
\end{tabular}

Source: data processed by SEM-PLS

\section{Hypothesis Testing Results 1}

Based on the table above, it can be seen that the t-count value of the organizational culture variable shows that the value is greater than the t-table, which is 1.96 which means that hypothesis 1 test in this study is that $\mathrm{HO}$ is rejected with the

Submitted: March 31, 2021; Accepted: April 04, 2021;

Published: April 24, 2021; Website: http://journalfeb.unla.ac.id/index.php/jasa 


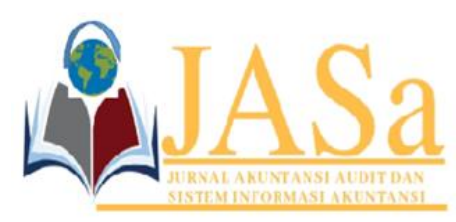

JASa (Jurnal Akuntansi, Audit dan Sistem Informasi Akuntansi)

Vol. 5 No.1/ April 2021

ISSN 2550-0732 print / ISSN 2655-8319 online

DOI; $10.36555 /$ jasa.v5i1.1598

statistical conclusion drawn that organizational culture has a significant effect on system quality management accounting information.

\section{Hypothesis Testing Results 2}

Based on the table above, it can be seen that the tcount value of the management accounting information system variable shows that the value is greater than the table, which is 1.96 which means hypothesis test 2 in this study, namely $\mathrm{HO}$ is rejected with the statistical conclusion drawn that the quality of the management accounting information system has a significant effect. managerial performance. From the results of calculations carried out in this study, the value of $f 2$ is 1.642 and 1.640 , so if the value of $f 2$ is above 0.35 which is the limit of the large effect size value, it can be stated that the effect size is for the influence of organizational culture on the quality of information systems. management accounting and managerial performance can be said to be large. Another measure used to evaluate the structural model is the organizational culture coefficient (R2). By presenting the relationship between the two variables of organizational culture and the quality of management accounting information systems and managerial performance which gives the calculation results of $\mathrm{R} 2=0.613$ and 0.610 . Therefore, it can be concluded that $61.3 \%$ and $61 \%$ of the variance in the variable quality of management accounting information systems and managerial performance are certainly explained by the organizational culture variables. It can be concluded that each of these models is strong. $38.7 \%$ and $39 \%$, respectively, were explained by other variables not examined outside of the study.

\section{Discussion}

In this study, the findings regarding organizational culture at Bhayangkara Tk. II Sartika Asih Bandung has been running very well but not perfect because it must have a value of $100 \%$,(ideal). The following are things that cause the organizational culture variable not to be said to be perfect but it can still be categorized as very good. Innovation and risk-taking cannot be said to be perfect due to the limited right to put forward new ideas and ideas with very strict limited access applied within the agency as well as the limited working hours to complete certain reports which must be completed immediately very accurately and according to facts there is. Attention to detail shows that in this study it is still not perfect due to time constraints in paying attention to more detailed matters regarding the presentation of the report which cannot be completed promptly if the specified date is too urgent. The orientation of the results still shows that in this study it is still not perfect because the presentation of the report is carried out through a gradual procedure so that the final result of the report that is done cannot be estimated at the beginning of the presentation. The orientation to people is still not perfect because if there are new employees who have not been employed for a long time in the agency, so they do not understand that their new job will be related to the interests of other divisions. The team orientation is still not perfect due to the limited access that each employee has between divisions, this is due to the different professions, ranks and positions each 


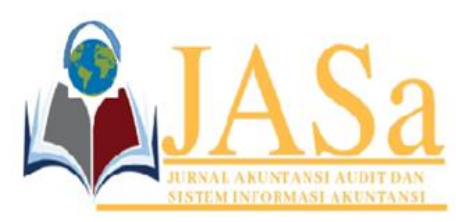

JASa (Jurnal Akuntansi, Audit dan Sistem Informasi Akuntansi)

Vol. 5 No.1/ April 2021

ISSN 2550-0732 print / ISSN 2655-8319 online

DOI; $10.36555 /$ jasa.v5i1.1598

employee has. Aggressiveness is still not perfect due to the competition that occurs among employees which aims to increase the individual qualifications of each employee. Stability is still not perfect because there are still reports that must be done and reported in a timely manner, which is increasing but the working hours provided are limited, this can hamper work stability. Based on the above analysis, hypothesis 1 (first) is accepted and states that organizational culture affects the quality of management accounting information systems. The higher or lower the organizational culture, the higher or lower the quality of the management accounting information system in an agency. In this study, the findings regarding the quality of management accounting information systems at Bhayangkara Tk. II Sartika Asih Bandung has been running very well but not perfect because it must have a value of $100 \%$ (ideal). The following are things that cause the variable quality of the management accounting information system to be not perfect, but it can still be categorized as very good. Broadscope still cannot be said to be perfect due to the lack of trust received by the recipient of the information and the limited scope, so employees must reconfirm the validity of the information data manually to be inputted before entering the process stage until it ends in the output results. Aggregation shows that in this study it is not yet perfect because there are still systems that are used manually and sources of information within the agency are carried out through divisions that have expertise in each different field. Timeliness still shows that in this study it is still not perfect because there are still reports that are submitted slightly beyond the predetermined time because there are reports that continue to increase every day with limited working hours. Integration is still not perfect because the manual system that is being run is not fully automatic or fully or completely computerized, so that if an employee does work to manually check the data does not come to work, it cannot be replaced by another employee because each employee has their own duties and responsibilities. Each. Based on the above analysis, hypothesis 2 (second) is accepted and states that the quality of the management accounting information system has an effect on managerial performance. The higher or lower the quality of the management accounting information system, the higher or lower its managerial performance will be.

\section{CONCLUSION}

Based on the results of research on discussions carried out through phenomena, problem formulations, hypotheses to research results, the authors conclude the results of research conducted at Bhayangkara Tk Hospital. II Sartika Asih Bandung regarding the influence of organizational culture on the quality of management accounting information systems and its impact on managerial performance as follows: Organizational culture has a significant effect on the quality of management accounting information systems. The dimension of team orientation is contained in the organizational culture at Bhayangkara Tk Hospital. II Sartika Asih Bandung is still experiencing problems as well as other dimensions that are running very well but not yet perfect. The quality of the management accounting information system has a significant effect on managerial performance. The four dimensions are reflected by a broad scope, 


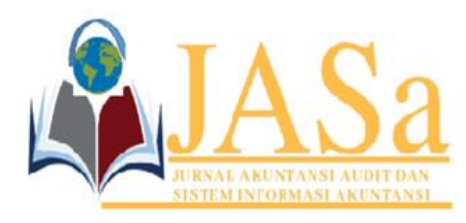

JASa (Jurnal Akuntansi, Audit dan Sistem Informasi Akuntansi)

Vol. 5 No.1/ April 2021

ISSN 2550-0732 print / ISSN 2655-8319 online

DOI;10.36555/jasa.v5i1.1598

aggregation, timeliness, and integration at Bhayangkara Tk Hospital. II Sartika Asih Bandung can be categorized as very good but cannot be said to be perfect.

\section{REFERENCES}

Ingga, I. (2017). Akuntansi Manajerial. Yogyakarta: Deepublish.

Kadri, T. (2018). Rancangan Penelitian. Yogyakarta: Deepublish.

Kreitner, R and Kinichi, A. (2014). Perilaku Organisasi. (Edisi sembilan). Jakarta: Salemba Empat.

Robbins, S.P and Judge, T.A. (2016). Perilaku Organisasi. Jakarta: Salemba Empat.

Salman, K.R dan Farid, M. (2016). Akuntansi Manajemen. Jakarta: PT. Indeks.

Tobari. (2014). Membangun Budaya Organisasi pada Instansi Pemerintahan. Yogyakarta: Deepublish.

Iba, Z. (2012). "Hubungan Karakteristik Informasi yang Dihasilkan oleh Sistem Informasi Akuntansi Manajemen Terhadap Kinerja Manajerial". Jurnal Kebangsaan. 1(2),36-39.

Wijayanti, S. (2018). "Pengaruh Karakteristik Sistem Informasi Akuntansi Manajemen terhadap Kinerja Manajerial”. Accounting Global Journal. 2(1), 64-75. 